\title{
Specially protected vascular plants of the Verkhneindigirsky Resource Reserve (Yakutia)
}

\author{
Evgenii Nikolin* \\ Institute for Biological Problems of Cryolithozone SB RAS, 677980 Yakutsk, Russia
}

\begin{abstract}
On the territory of the Verkhneindigirsky Resource Reserve, located near the North-Eastern border of the Sakha (Yakutia) Republic, the distribution of 16 species of vascular plants listed in the regional Red Book of Yakutia was revealed.
\end{abstract}

The Verkhneindigirsky Resource Reserve of republican significance is located in the Oymyakonsky ulus of the Republic of Sakha (Yakutia), near the border of the Magadan Oblast' of the Russian Federation and the north of the Khabarovsk Kraj. It is located within the Oymyakon highlands with elevations from 850 to $1200 \mathrm{~m}$ above sea level, in the south passing into the spurs of the Suntar-Hayata range with elevations up to $1700 \mathrm{~m}$. The structure of the flora of the Verkhneindigirsky resource reserve was discussed earlier [1,2]. In this case, we will focus only on plants whose conservation status is confirmed by the Red Book of the Republic of Sakha (Yakutia). During the historical period, 3 Red Books were published in Yakutia [3-5], of which its edition, published in 2017, is currently relevant. In the course of field studies conducted in 2008 and 2012, 16 species listed in the latest issue of the Red Book were identified on the territory of the Verkhneindigirsky resource reserve.

\section{List of species growing on the territory of the Verkhneindigirsky resource reserve, included in the 3rd edition of the Red Book of the Republic of Sakha (Yakutia)}

Fam. Potamogetonaceae Dumort.: Potamogeton sibiricus A. Benn. - not rarely: in shallow water at the southern end of the lake Labyngkyr. It is included in the list (Annex 1) of species that need special attention to their state in nature and monitoring. Earlier, in the second edition of the Red Book, it had the status IV - a little-studied sub-endemic of Yakutia [4]. However, after an in-depth study of representatives of this genus in Yakutia [6], the conservation status of this species was revised.

Fam. Poaceae Barnh.: Poa filiculmis Roshev. - not rarely: mixed floodplain woodlands, river alluvium, stone scree, rocks. Status $3 \mathrm{~b}-\mathrm{a}$ rare species with a significant range, but occurring sporadically within Yakutia.

*Corresponding author: enikolin@yandex.ru 
Fam. Cyperaceae Juss.: Carex holostoma Drej. - rarely: sedge and sphagnum swamps, pebbles. It is included in the list (Annex 1). A rare species, the distribution of which in Yakutia needs to be clarified.

C. stylosa C. A. Mey. - rarely: swampy waterholes. It is included in the list (Annex 1). A rare species, the distribution of which in Yakutia needs to be clarified.

Kreczetoviczia caespitosa (L.) Tzvelev - not rarely, at the southern end of lake Labyngkyr: bogs, swampy larch woodlands. Status $3 b-$ a rare species with a significant range, but occurring sporadically within Yakutia.

Fam. Ranunculaceae Juss.: Ranunculus grayi Britt. - rarely: it is marked in the southeastern end of the lake Labyngkyr, in the breakup of the mountain " Yubilejnaya ", mossy stones, tundra lawns in the valley of the stream. Status $3 b-a$ rare relict species with a narrow ecological location (usually-gravelly slopes among tundras, larch woodlands, thickets of cedar elfin (Pinus pumila)).

Fam. Papaveraceae Juss.: Papaver minutiflorum Tolm. - rarely: at the base of the coastal shaded cliffs. It is included in the list (Annex 1). In the first edition of the Red Book, it had the status of IIIb, as a rare species, endemic of the USSR North-East [3].

Fam. Droseraceae Salisb.: Drosera anglica Huds. - it is marked in one point: sphagnum swamp on the shore of a small lake located on the low ridge, in the left bank of the Labyngkyr River. Status $3 b-a$ rare species with a narrow ecological focus.

Fam. Crassulaceae J. St.-Hil.: Rhodiola rosea L. s.1. - once, in the river sediments of the Taryn-Yuryakh River, below the mouth of the Bayagap River, a rhizome of this species was found, brought in by a flood from the upper reaches. Probably located in the Reserve. Status $3 b-$ a rare species with resource value.

Fam. Rosaceae Juss.: Sorbaria grandiflora (Swiit) Maxim. - often: larch woodlands, sparse thickets of cedar elfin, shrubs thickets of mountain streams, stone scree, rocks. It is included in the list (Annex 1). In the first edition of the Red Book, under the synonym $S$. pallasii (G. Don fil.) Pojark., it had the status of IIIg, as a rare species [3].

Fam. Fabaceae Lindl.: Astragalus vallicola Gontsch. - it is marked in one point: stone scree on the eastern slope of Chasovoj Mountain. Status $3 \mathrm{~d}-\mathrm{a}$ rare species with a limited area, part of which is located in Yakutia. It is endemic to the relict steppes of the North-East of Russia.

Oxytropis ochotensis Bunge - quite rare: overgrown river alluvium (sand, pebbles). Status $3 \mathrm{~d}-\mathrm{a}$ rare species with a limited area, part of which is located in Yakutia. It is endemic to the relict steppes of the North-East of Russia.

O. subnutans (Jurtz.) Jurtz. - rarely: dry larch woodlands. Status $3 \mathrm{~d}-$ a rare species with a limited area, part of which is located in Yakutia. It is endemic to the relict steppes of the North-East of Russia.

Fam. Umbelliferae Juss.: Phlojodicarpus villosus (Turcz. ex Fisch. et C. A. Mey.) Ledeb. - it is marked in one point: stony larch woodlands, stone scree on the north-eastern slope of Chasovoj Mountain. Status $2 \mathrm{~b}-\mathrm{a}$ species whose population is declining as a result of overuse by humans.

Fam. Ericaceae Juss.: Rhododendron redowskianum Maxim. - often at the southern end of lake Labyngkyr: larch woodlands, thickets of cedar elfin, tundra, mossy tundra meadows, stone scree, rocks in the valleys of streams. Status $3 \mathrm{~d}-$ a rare species with a significant range, but located in Yakutia on the northern border of the area.

Fam. Lentibulariaceae Rich.: Pinguicula spathulata Ledeb. - quite often in the southern end of the lake Labyngkyr: sphagnum larch woodlands, sphagnum swamps. It is included in the list (Annex 1). In the second edition of the Red Book, it had the status of IIIb - rare of Yakutia [4]. According to recent observations in North-Eastern Yakutia, significant areas of its growth and significant abundance in swampy communities have been identified. 
The density of the floral survey of the Verkhneindigirsky Resource Reserve continues to be low. Without a doubt, with a deeper study of this territory, the list of specially protected plants can be significantly expanded. At this time, a significant number of rare and vulnerable vascular plants have been identified here, which determine the uniqueness of the nature of the Resource Reserve and justify the expediency of protecting this territory: 1 species declining in number, 9 rare species (including 3 endemic to the North-East of Russia) and 6 species that need special attention and monitoring of the state of their populations. It is recommended to expand the research in this area and consider the organization on its basis, with the addition of the adjacent protected area of the Magadan Oblast' - the Resource Reserve "Hinike", a State Nature Reserve. This would significantly increase the area and effectiveness of the protection of many endemics distributed in the Yano-Kolymo-Okhotsk Center of Florogenesis [7].

\section{References}

1. E. Nikolin, Botanical journal 105 (7) (2020)

2. E. Nikolin, Bulletin of the Buryat State University. Biology, geography 1 (2021)

3. The Red book of the Yakutian ASSR. Rare and endangered plant species (Moscow: Reart, Yakutsk: Sakhapoligrafizdat, 1987)

4. The Red book of the Republic of Sakha (Yakutia), Rare and endangered species of plants and fungi (Yakutsk, 2000)

5. The Red book of the Republic of Sakha (Yakutia), Rare and endangered species of plants and fungi (Moscow, 2017)

6. A. Bobrov, O. Mochalova, News of the taxonomy of higher plants 45 (2014)

7. E. Nikolin, Bulletin of the North-Eastern Federal University 9 (2) (2012) 